\title{
TEACHER'S QUESTIONS IN EFL CLASSROOM INTERACTION
}

\author{
Danu Angga Vebriyanto \\ danu.a.v@gmail.com \\ Graduate Program of PPS UNNES
}

\begin{abstract}
Questioning is a basic method implemented by teacher in order to build interaction in the classroom and also to stimulate the students to perform their speaking skill in target language. The present study attempted to describe the types of questions that the teacher usually applies in the classroom during teaching and learning process, to find out the teacher's purposes of applying those levels of questioning, and to describe the effects of applying the levels of questioning for the students' understanding of English, and to identify students' oral responses towards teacher questions. The data were collected by recording the teaching and learning process and interviewing the English teacher. Based on the research findings, it was discovered that the teacher utilized certain types of questions. Referential-open questions that can elicit longer responses were $31 \%$. On the other hand, the percentage of display-closed questions was $69 \%$. Questions that are categorized as display/closed questions were widely used for checking students' understanding of the materials questions that categorized as referential/open questions were widely used for looking for certain information from the students. It was found that in all season $70 \%$ of students' responses were in form of words. The production of words was the effect of employing display or closed question. In the other hand, students' responses in form of sentence were 7 sentences. It was the effect of employing referential or open question.
\end{abstract}

Keywords: teacher's questions, EFL, classroom interaction 


\section{INTRODUCTION}

Teacher's question or teacher questioning is one of the most common techniques in the classroom interaction. Galls as cited in Richard (1996) states that more than a half of classroom talk is dominated by questioning and answering. David (2007) adds that teacher's question is an important aspect of classroom interaction in second language classroom which has obtained large amount of attention from researchers or scholars.

Teachers' question is one part of teacher talk based on methods of classroom interaction analysis i.e. Foreign Language Interaction Analysis (FLINT) developed by Moskowits. Study conducted by Yanfen and Yuqin (2010) on teacher talk in classroom interaction reveals that teacher initiates the interaction mostly by questioning. This fact gives us general view about the connection between teacher's question and classroom interaction, meaning that the discussion about teacher's question cannot be separated from interaction. For language teachers, interaction is very essential. It is "the hearth of communication". According to Brown (2001), Interaction is the exchange of thoughts, feelings, and ideas which is conducted by two or more people, and mutual effect will be produced in both communicators. In the classroom context, Kalatari (2009) defines classroom interaction as "interaction between teacher and students in the classroom".

Interaction cannot be produced easily and naturally without some initiatives or efforts from teachers. Teachers need to constantly engage and stimulate the students to be actively involved in classroom interaction. Furthermore, the stimulus from teachers in the beginning of classroom interaction is very crucial to build interactive language classroom. One of the paramount techniques for teachers to initiate and maintain interaction in the classroom is by developing questioning strategies or techniques. As the EFL students generally reluctant to initiate and maintain the interaction, teachers' questions supply important stepping stone for students to join in the classroom interaction. (Brown, 2001) 
Teacher's Questions in EFL Classroom Interaction ...

\section{BACKGROUND LITERATURE}

\section{Teacher's Questions in EFL Classroom Interaction}

Considering about the importance of teachers questioning in the classroom interaction, the investigation on teacher's questioning behavior has been an important issue. The studies on teacher's questioning show that teachers favor asking a great number of questions in the classroom with different rationale. It is revealed that teacher's question has essential role. The activity of questioning and answering is considered as form of communication which is commonly used by students and teachers in the classroom. (Shen, et.al 2012)

Furthermore, many studies investigate the effect of displayclosed questions and referential-open questions used by teachers upon students' language production in term of length and complexity. Studies conducted by Brock as cited in Lynch (1991), also Al Mu'aini (2012) reveal that referential questions asked by teacher initiates longer and extensive oral responses from students whereas display question results short and closed answer. On the contrary, Shomoosi (2004) claims that display-closed questions sometimes produce longer responses (five-minute answer) from students. From the studies above, we can see that there is different result of studies on the effect of either display-closed questions or referential-open questions to students' language production. This difference basically can be understood since each research is hold in different place with different participants. This difference means that the study on teacher's question or classroom questioning is still worth investigated.

Obviously, from the elaboration above, we can see that questioning is typically implemented by teachers in their teaching process. It is a basic method implemented by teacher in order to build interaction in the classroom and also to stimulate language production of students. Unfortunately, some teachers do not realize about the importance of using appropriate questioning types and strategy to help the students trying to produce language. They do not realize that their questions will give consequence on student language production. In some cases, poor questioning makes classroom interaction tend to be boring and students are unmotivated to speak or 
perform their language production skill.

Research which is conducted on the use of questions in the classroom reveals that the majority of teachers do not utilize effective questioning techniques. When we review the research, we can discover that teachers' questioning has crucial rule in the classroom and teachers need to develop their questioning technique. Proper questioning types will result in the enforcement of students to perform their language competence as the respond to teachers' questions. (Sadker,2011)

Concerning above explanation, this study aims at examining teacher's questioning types, teacher's purpose of questioning and students' responses to several types of teacher's questions. The study on this area is still worth investigated since there is no conclusive result.

\section{Question and Teacher's Question}

Cotton (2012) states that question is any sentence which has interrogative form or function. Aizikovitsh et.al. (2011)describe question as an inquiry expression which encourages or asks for response or rejoinder. Richard Nordquist (2013) defines:

"Question is a type of sentence expressed in a form that requires (or appears to require) an answer. Also known as an interrogative sentence, a question is generally distinguished from a sentence that makes statement, delivers a command, or expressed an exclamation."

He adds that in terms of syntax, the character of question is an inversion between the subject and the first verb in the verb phrase. There is also interrogative pronoun in the beginning or tag question in the end.

In daily communication, the use of question is unavoidable. When communicating, people use various forms of question in order to get some information from their interlocutor. A question is also a good device to maintain the communication with other people. Obviously, a question has the important function in conversation. Question has the significant function not only in general 
context, but also in teaching-learning (classroom) context. Cotton states that classroom questioning has long and venerable history since Socrates, the Greek philosopher, with his method of questioning (Socratic method) guides the students by challenging assumptions, exposing contradictions, and leading to new knowledge and wisdom. In addition, classroom questioning attracts researchers and practitioners to be their topic of studies because of its extensive use as current teaching technique. Classroom questioning also takes the second most popular teaching technique after lecturing. In teachinglearning process, classroom questioning is widely used by teachers for about $35-55 \%$.

In addition, Richard and Lockhart state that there are some reasons why questions widely used by teachers as teaching technique. First, questions stimulate and maintain students' interest. Second, they encourage students to think and focus on the content of the lesson. Third, they enable a teacher to clarify what a student has said. Fourth, they enable a teacher to elicit particular structures or vocabulary items. Fifth, they enable teachers to check students' understanding. Sixth, they (questions) encourage student participation in a lesson.

Furthermore, study conducted by Millah (2009) on classroom interaction reveals that asking question is the activity that dominates teacher talk $(21,75 \%)$ and most of students talk is dominated by giving responses $(33,75 \%)$. This study is in line with Liu and Zhao study which is entitled "A Study of Teacher Talk in Interactions in English Classes". The study reveals that teachers tend to employ large amount of questions when they initiate classroom interaction. Based on the observation, Teacher talks are dominated by questioning for about $48 \%$.

The elaboration above gives us clear insight about question and teacher's question. Question is a meaningful linguistics unit (sentence) or utterance which has interrogative sense, meaning that it is intended to get some information or responses from the listener or reader. The form of question is not only in form of interrogative by using question word, auxiliary verb, and tag, but also in form of declarative sentence with rising intonation. 
Questioning plays vital role in daily communication. It can be used as a tool to create and maintain communication. These functions also can be implemented in classroom context. Questioning is commonly used by teacher as an instrument to create interaction in the classroom. It is the best way to encourage some responses from student and also to check students understanding about material which has been studied. Concisely, questioning provide large amount of benefit and function for classroom interaction. The comprehensive discussion about questioning or teachers' question will be elaborated in the next section.

\section{Types of Teacher's Questions}

Teacher's questions have been classified in a number of ways. Some experts categorized types of questions into display and referential question, open and closed question. According to Brown (2001), display question is type question in which the answer of the question is already known by the teacher. This type of question is asked for students in order to check whether they know the answer or not. Based on several studies, these kinds of questions are generally found in the classroom interaction. Teachers highly use display questions based on their purposes that is to check students' knowledge. (Yang, 2011)

When in display questions teacher have already known the answers of the questions, in referential questions, teachers do not know the answer of the questions. Ellis as cited in Al-Muaini states that "referential questions are genuine or real questions." The purpose of this question is to acquire some information that teachers do not know from students. (Husein, 2012) Based on research conducted by Long and Sato as cited in Lynch (1991), Referential question is rarely asked by teacher in the classroom interaction. From $76 \%$ of teacher's question proportion, only $14 \%$ are asked by using referential questions.

The second category of question is open and closed question. Nunan and Lamb as cited in Al-Farsi (2012) describe open questions as type of question which can promote broad response from students. They are types of questions that are broad and permit 
more than one acceptable answer from students. Eggins and Slade (1997) suggest that open questions are type of question that "seek to elicit completion of a proposition from the addressee" or in another words, it demands factual or opinion information from the addressee. Open question commonly recognized in form of whinterrogative or wh-question. It can be concluded that teachers who ask by using this type of the possible answer from students. The responses will be varied according to students. Compared to open questions, Ellis as cited in Al-Farsi states that closed questions are types of questions which produce only one acceptable answer or response from students. These types of questions have the purposes of demanding confirmation or agreement with factual or opinion information. The form of closed questions are commonly realized by polar (yes-no) interrogatives.

From the explanation above, it can be concluded that types of teacher's questions can be classified into several categories. Based on Bloom's taxonomy of educational objectives, teacher's questions are categorized into knowledge, comprehension, application, analysis, synthesis, and evaluation question. Those levels of questions are developed based on students' level of thinking so that the higher level of questions will expect the higher students' level of thinking. The other types of questions are display and referential questions, open and close-ended questions. Display questions are types of questions in which the teacher has already known the answers of the questions. It is used to check students' understanding about the lesson that they have studied. Conversely, referential questions are types of questions that teacher actually does not know the answer of the questions. Teacher really wants to know particular information from students. These questions commonly elicit long response from students. Another category is open and closed questions. In open questions, teacher cannot expect possible answer form students. The answer will be varied according the students. Some researchers insist that open questions tend to be open and vice versa. In the other hand, closed-ended questions are questions that only have one acceptable answer so that teacher has already known the answer. In the present study, teachers' questions would only be cate- 
gorized into display and referential questions, open and close-ended questions. It is because the objective of the study is focused on the classroom interaction. In the other hand, types of teacher's questions based on Bloom taxonomy tend to focus on students' level of thinking.

\section{Functions and Purposes of Teacher's Questions}

Christenbury, Kelly and Kinsella as cited in Brown (2001) propose some functions of teacher questions in the classroom interaction. Teacher's questions can a) give students the drive and the opportunity to produce language contentedly because EFL student generally afraid of initiating classroom interaction without any stimulus from the teacher. Silent students will get a great chance to produce their language (communicate) if appropriate questions are addressed to them, b) set off some stimulus for students to communicate and interact each others. One question may be all that is needed to start a discussion; without the initial question, however, students will be hesitant to start the process c) give the instructor immediate feedback about student comprehension. After posing a question, a teacher can use the student response to diagnose linguistic or content difficulties. Grammatical or phonological problem areas, for example, may be exposed through the student's response and give the teacher some specific information about what to treat, d) provide students with opportunities to find out what they think by hearing they say. As they are nudged into responding to questions about, say, a reading or a film, they can discover what their own opinions and reactions are. This self-discovery can be especially useful for prewriting activity.

Tanaka as cited in Nishimura (2012) proposes three functions of question. The first is "interpersonal function". It means that question can set up, keep, and modify the relationship between questioner and respondent. The second is "information-gathering function", meaning that question can be an instrument to get some information about certain issue or topic. The last is "meaning-creating function". It means that a new idea can be produced by questioning. 
Kauchak and Eggen as cited in Xiaoyan (2008) add that in the classroom, teacher's questions serve several functions. They are diagnostic, instructional and motivational function. As diagnostic tool, teacher's questions are used to diagnose what students know and how students think about certain topics. As instructional function, teacher's questions can assist the students to study new information in the learning process. The last function according to Kauchak and Eggen is motivational function. Teacher's questions can be a tool that engages the students to be actively involved in the classroom discourse and encourage or challenge their thinking.

Dealing with the purposes of teacher questions, Cotton (2012) provides variety of purposes emerge from the variety of literature analysis. Teacher's questions are used to a) develop interest and motivate students to become actively involved in lessons, b) evaluate students' preparation and check on homework or seatwork completion, c) develop critical thinking skills and inquiring attitudes, d) review and summarize previous lessons, e) nurture insights by exposing new relationships, f) assess achievement of instructional goals and objectives, g) stimulate students to pursue knowledge on their own

Furthermore, Cohen et.al. (2004) give in depth purpose of teacher's questions in the classroom. They suggest the purpose of teacher's questioning based on several learning stages in the classroom. In the introduction stage, teachers' questions are used a) to establish human contact; b) to assist in establishing set induction devices; c) to discover what the class knows; d) to revise previous work; e) to pose problems which lead to the subject of the lesson. In the presentation stage, teacher's questions are used to a) maintain interest and alertness; b) to encourage reasoning and logical thinking; c) to discover if students understand what is going on. In the application stage, teacher's questions are used a) to focus and clarify; b) to lead the students to make observations and draw inferences for themselves; c) to clear up difficulties, misunderstandings and assist individual student. In the last stage, conclusion, teacher's questions are used a) to revise the main point of the lesson; b) to test the result of the lesson, the extent of students understanding 
and assimilation; c) to suggest further problems and related issues.

From the elaboration above, it can be concluded that teacher's questions have significant role in the classroom interaction. It can give numerous benefits for language student, classroom interaction, and the objective of language classroom.

\section{Relationship Among Types of Teacher's Questions, Pur- poses of 'Teacher's Questions and Students' Oral Responses}

Types of teacher's questions, purposes of teacher's questions and students' oral responses have a positive relationship. Chaudron states that student's target language production (students' oral responses) in from of correct and meaningful responses might be assisted by teacher's question. It was based on some second language studies which concerned with teacher's questions and students' target language production (students' oral responses). Chaudron (1988) adds that in order to keep students' attention, elicit students' verbal responses, and assess students' learning progress, teacher's questions represent as a primary tool.

Furthermore, a study that has been done by Brock on the effect of teacher's questions on students' language production revealed that students' responses for teacher's referential questions were significantly longer and syntactically more complex. It was compared to students' responses for teacher's display questions which were short.

On the contrary, Shomoosi (2004) claims that display-closed questions sometimes produce longer responses (five-minute answer) from students. From the studies above, we can see that there is different result of studies on the effect of either display-closed questions or referential-open questions to students' language production. This difference basically can be understood since each research is hold in different place with different participants. This difference means that the study on teacher's question or classroom questioning is still worth investigated.

\section{METHOD}

It is essential to apply a proper research design in order to at- 
tain research objectives. The present study describes teacher's questioning types, purpose of questioning and also students' responses in natural setting. Hitchcock and Hughes (1995) insisted that social behavior in natural setting is the main concern of qualitative approach. It means that the participants of the research are not taken into laboratory or modified situation.(Creswell, 2009) Since the present study concerns with the classroom interaction in the natural setting, qualitative approach will be appropriate to be employed in this study.

The present study is also categorized as descriptive research. Cohen et.al. (2007) state that descriptive research "looks at individuals, groups, institutions, methods and materials in order to describe, compare, contrast, classify, analyse and interpret the entities and the events that constitute their various fields of inquiry." In line with this statement, the present study aims at describing, analyzing and interpreting teacher questioning types, purposes and also students' responses in the classroom.

\section{Setting and Timing}

The present study was conducted in SMK Palapa Semarang which is situated on Jln. Untung Suropati Mijen Semarang. This school has got excellent accreditation score as well as ISO 9001:2008. This school was chosen because of the accessibility and availability of time. Moreover, some studies dealing with teacher's questions were conducted at junior and senior high school, so the present study would be a pioneer and expected to give a different result. The participant of the present study was an English teacher and her students in XI-TKJ class in the academic year of 2012/2013. The present study was conducted from $1^{\text {st }}$ until $15^{\text {th }}$ May 2013.

\section{Sources of Data}

Moleong (2009) stated that the data which were collected in qualitative research were in form of words, picture, and not in form of numbers. The source of data could be from interview script, photo, videotape, notes, and other documents. In 
line with Moleong's account, the data of the present study were taken from the transcript of interaction between the English teacher and students in the classroom as well as the interview with English teacher.

\section{Constructing Trustworthiness}

According to Creswell and Miller as cited in Creswell (2009), Validity is one of the strong points in qualitative research. It was needed to verify and clarify the accuracy of the finding on the perspective of the researcher, participants, and the readers of the account. In order to verify the accuracy or the validity of the research finding, there were certain procedures that had been utilized.

The first procedure that had been implemented to verify the accuracy or the validity of the research finding was triangulation. Different sources of data from observation (by means of video recording and note-taking) and interview had been obtained and examined in order to build coherent explanation.

The second procedure was peer debriefing. Creswell (2009) argued that this procedure is used to boost the accuracy of the report or explanation. In this procedure, a person was involved to make a review and questions about the study. This procedure can enhance the validity of the research. In the present study, the peer debriefing are the supervisor of the researcher and fellow students.

\section{Data Analysis Technique}

There were several steps that have been employed in order to analyze the data. The first step was collecting all data from observation (by means of video-recording and field-notes) and interview. The second step was transcribing and coding the data. All of recorded data, either video record from classroom interaction or audio record from interview were transcribed. The utterances of the teacher were given T code, whereas students' utterances were given $\mathrm{S}$ or Ss code. The third step was interpreting the data. The researcher identified teacher's questioning types, 
teacher's purpose of questioning and students' responses to several types of teacher's questions. Concluding the finding and discussing the research finding was the last step in data analysis processes. The researcher presented some conclusions from the research finding which is related to the objective of the research.

\section{RESULT}

\section{Types of Teacher's Questions}

Based on the analysis of the transcription of the teaching and learning process in the first session, the amount of questions which are posed by teacher are 33 questions. The type of question that is asked frequently by teacher is display and open question, which the teacher has already known the answer and there is only one acceptable answer. This situation is shown in Table 1 below.

\section{Table 1 Teacher's Questions}

\begin{tabular}{|c|c|c|c|c|c|c|c|c|}
\hline \multirow{3}{*}{$\begin{array}{l}\text { Types of teach- } \\
\text { er's questions }\end{array}$} & \multicolumn{6}{|c|}{ Teaching stages } & \multirow{2}{*}{\multicolumn{2}{|c|}{$\begin{array}{l}\text { Total } \\
\text { (per } \\
\text { type) }\end{array}$}} \\
\hline & \multicolumn{2}{|c|}{$\begin{array}{c}\text { Pre- } \\
\text { activity }\end{array}$} & \multicolumn{2}{|c|}{$\begin{array}{l}\text { Whilst- } \\
\text { activity }\end{array}$} & \multicolumn{2}{|c|}{$\begin{array}{l}\text { Post- } \\
\text { activity }\end{array}$} & & \\
\hline & $\mathrm{N}$ & $\%$ & $\mathrm{~N}$ & $\%$ & $\mathrm{~N}$ & $\%$ & $\mathrm{~N}$ & $\%$ \\
\hline $\begin{array}{l}\text { Display/Closed } \\
\text { question }\end{array}$ & 1 & 5 & 21 & 95 & - & - & 22 & 66 \\
\hline $\begin{array}{l}\text { Referential/ } \\
\text { Open question }\end{array}$ & - & - & 11 & 100 & - & - & 11 & 33 \\
\hline & otal & Ques & ons & & & & 33 & 100 \\
\hline
\end{tabular}

From the table above, it can be seen that display and closed question dominates for about $66 \%$ (22 questions) out of 33 questions. On the other hand, referential and open question in which the teacher does not the answer and there is more than one acceptable answer, have the total of 11 questions (33\%).

The second session uncovers almost the same finding with the first session. Display and opened question is the type of question that is frequently used by the teacher. The attention-grabbing finding in the session 2 is the increasing number of question which 
is asked by the teacher. The total numbers of questions asked by teacher are 70 questions. Forty-nine questions are categorized as display and closed question. Twenty-one questions are categorized as referential and opened question. This escalation is influenced by the learning focus of session 2 on agreement and disagreement expression and concessive conjunction (grammar). To figure out the distribution of teacher's questions in the session 2 , it is necessary to study the following table.

\section{Table 2 Teacher's Questions}

\begin{tabular}{|c|c|c|c|c|c|c|c|c|}
\hline \multirow{3}{*}{$\begin{array}{l}\text { Types of teach- } \\
\text { er's questions }\end{array}$} & \multicolumn{6}{|c|}{ Teaching stages } & \multirow{2}{*}{\multicolumn{2}{|c|}{$\begin{array}{l}\text { Total } \\
\text { (per } \\
\text { type) }\end{array}$}} \\
\hline & \multicolumn{2}{|c|}{$\begin{array}{l}\text { Pre- } \\
\text { activity }\end{array}$} & \multicolumn{2}{|c|}{$\begin{array}{l}\text { Whilst- } \\
\text { activity }\end{array}$} & \multicolumn{2}{|c|}{$\begin{array}{l}\text { Post- } \\
\text { activity }\end{array}$} & & \\
\hline & $\mathrm{N}$ & $\%$ & $\mathrm{~N}$ & $\%$ & $\mathrm{~N}$ & $\%$ & $\mathrm{~N}$ & $\%$ \\
\hline $\begin{array}{l}\text { Display/Closed } \\
\text { question }\end{array}$ & 1 & 2 & 48 & 98 & - & - & 49 & 70 \\
\hline $\begin{array}{l}\text { Referential/ } \\
\text { Open question }\end{array}$ & 1 & 4 & 19 & 90 & 1 & 4 & 21 & 30 \\
\hline \multicolumn{7}{|c|}{ Total Questions } & 70 & 100 \\
\hline
\end{tabular}

Same as the distribution in the first session, display and closed questions in this session are frequently used by teacher to ask the translation of words or phrases for the students.

In order to get a comprehensive understanding of types of teacher's questions in two sessions under analysis, the table bellow provides the distribution of types of teacher's questions in two sessions.

Tabel 3 Distribution of Teacher's Questions

types of teacher's

questions

\begin{tabular}{crrrrr}
$\begin{array}{c}\text { Session } \\
1\end{array}$ & \multicolumn{2}{c}{$\begin{array}{c}\text { Session } \\
2\end{array}$} & \multicolumn{2}{c}{ Total } \\
\hline $\mathrm{N}$ & $\%$ & $\mathrm{~N}$ & $\%$ & $\mathrm{~N}$ & $\%$
\end{tabular}

\begin{tabular}{ccccccc} 
Display/Closed question & 22 & 66 & 49 & 70 & 71 & 69 \\
Referential/Open question & 11 & 33 & 21 & 30 & 32 & 31 \\
Total & 33 & 100 & 70 & 100 & 103 & 100 \\
\hline
\end{tabular}


The table shows that in two sessions under analysis, there was an improvement in the numbers of questions that are asked by teacher. The uses of display-closed questions by teacher were dominant apart from the different focus of learning. Display/ closed questions were frequently used by teacher to ask for translation of certain word, phrase, even sentence to the students. On the other hand, referential-open questions which have low percentage, are frequently used by the teacher to ask for student's personal information and also students' opinion about certain topic.

\section{Teacher's Purposes of Applying Different Types of Ques- tions}

Based on the interview with the teacher, it was revealed that there were some purposes of asking several types of questions to students. The teacher said that she commonly used yes-no question which is categorized as display/closed question. The purpose of using this type of question is to check students' understanding about the underlying material. The other type of question that was generally used by the teacher was wh-question which can be categorized as referential/open question. The teacher said that the purpose of using wh-question was to ask for detail information or answer from students.

The facts above correspond with the result of the analysis of the transcription of the teaching and learning process in the all session. Questions that are categorized as display/closed questions were widely used for checking students' understanding of the materials that were being discussed in the class. In the first session and the second session, the teacher asked students to translate some words or phrases by using some display/closed questions. It was done by the teacher in order to know whether students understand the material or not. Furthermore, based on the analysis of the transcription of the teaching and learning process in the all session, questions that categorized as referential/open questions were widely used for looking for certain information from the students. Besides that, referential/open questions were also used for stimulating students' opinion about something. 
3. Students' responses toward teacher's questions in terms of verbal language production in EFL classroom interaction

Students' Responses: First Session

\begin{tabular}{|c|c|c|c|c|c|c|c|c|c|c|c|}
\hline \multirow{2}{*}{$\begin{array}{l}\text { Types of } \\
\text { teacher's } \\
\text { questions }\end{array}$} & \multicolumn{2}{|c|}{ Letter } & \multicolumn{2}{|c|}{ Syllable } & \multicolumn{2}{|c|}{ Word } & \multicolumn{2}{|c|}{ Phrase } & \multicolumn{2}{|c|}{$\begin{array}{l}\text { Sen- } \\
\text { tence }\end{array}$} & \multirow{2}{*}{$\begin{array}{l}\text { Total } \\
\text { (per } \\
\text { type) }\end{array}$} \\
\hline & $\mathrm{N}$ & $\%$ & $\mathrm{~N}$ & $\%$ & $\mathrm{~N}$ & $\%$ & $\mathrm{~N}$ & $\%$ & $\mathrm{~N}$ & $\%$ & \\
\hline Display/ & & & & & & & & & & & \\
\hline $\begin{array}{l}\text { Closed } \\
\text { question }\end{array}$ & - & - & - & - & 10 & 71 & 3 & 21 & 1 & 7 & 14 \\
\hline $\begin{array}{l}\text { Referen- } \\
\text { tial/ Open } \\
\text { question }\end{array}$ & - & - & - & - & 4 & 44 & 2 & 22 & 3 & 33 & 9 \\
\hline Total & - & - & - & - & 14 & 61 & 5 & 26 & 4 & 17 & 23 \\
\hline
\end{tabular}

Students' Responses: Second Session

\begin{tabular}{|c|c|c|c|c|c|c|c|c|c|c|c|}
\hline \multirow{2}{*}{$\begin{array}{l}\text { Types of } \\
\text { teacher's } \\
\text { questions }\end{array}$} & \multicolumn{2}{|c|}{ Letter } & \multicolumn{2}{|c|}{ Syllable } & \multicolumn{2}{|c|}{ Word } & \multicolumn{2}{|c|}{ Phrase } & \multicolumn{2}{|c|}{ Sentence } & \multirow{2}{*}{$\begin{array}{c}\text { Total } \\
\text { (per } \\
\text { type) }\end{array}$} \\
\hline & $\mathrm{N}$ & $\%$ & $\mathrm{~N}$ & $\%$ & $\mathrm{~N}$ & $\%$ & $\overline{\mathrm{N}}$ & $\%$ & $\mathrm{~N}$ & $\%$ & \\
\hline Display/ & & & & & & & & & & & \\
\hline $\begin{array}{l}\text { Closed } \\
\text { question }\end{array}$ & - & - & - & - & 20 & 83 & 4 & 17 & - & - & 24 \\
\hline Referential/ & & & & & & & & & & & \\
\hline $\begin{array}{l}\text { Open ques- } \\
\text { tion }\end{array}$ & - & - & - & - & 8 & 62 & 2 & 15 & 3 & 20 & 13 \\
\hline Total & - & - & - & - & 28 & 76 & 6 & 16 & 3 & 8 & 37 \\
\hline
\end{tabular}

\section{DISCUSSION}

\section{Types of Teacher's Questions}

From the analysis of the transcription of teaching and learning process in the first and second session, it was discovered that the teacher utilized certain types of questions. Similar to some of pre- 
vious research such as Al Mu'aini (2012), Yang and Yuliyanti (2008), the research finding of the present study revealed that referentialopen questions that were used by the teacher were considerably fewer than the display-closed questions. Referential-open questions that can elicit longer responses had the percentage 31\%. On the other hand, display-closed questions had the percentage 69\%. These proportions of types of questions inhibit the students from performing their language competence extensively. Furthermore, most of the teacher's questions functioned as a way of checking students' understanding.

The teacher expected that students would give a response when she asked questions. However, students are used to living in a school and social system where students talk is commonly not encouraged and where a student's response is characteristically brief, monosyllable word and syntactically less complex then it made the teacher difficult to use questions as an effective teaching tools. Therefore, encouraging students to talk more is the primary goal. The atmosphere for classroom talk needs to be built by teacher. In order to encourage students' responses, teacher also needs to give opportunities for students.

\section{Teacher's Purposes of Applying Different Types of Ques- tions}

It could be seen in the research finding above that teacher employ display-closed questions and referential-open questions. Different purposes were created by the teacher when she posed some questions. Based on the interview with the teacher, it was revealed that there were some purposes of asking several types of questions to students. The teacher said that she commonly used yes-no question which is categorized as display/closed question. The purpose of using this type of question is to check students' understanding about the underlying material. The other type of question that was generally used by the teacher was wh-question which can be categorized as referential/open question. The teacher said that the purpose of using wh-question was to ask for detail information or answer from students. 
The facts above correspond with the result of the analysis of the transcription of the teaching and learning process in the all session. Questions that are categorized as display/closed questions were widely used for checking students' understanding of the materials that were being discussed in the class. In the first session and the second session, the teacher asked students to translate some words or phrases by using some display/closed questions. It was done by the teacher in order to know whether students understand the material or not. Actually, this questioning purpose was in line with Cotton's and Cohen et.al. framework about teacher's questioning purposes.

Furthermore, based on the analysis of the transcription of the teaching and learning process in the all session, questions that categorized as referential/open questions were widely used for looking for certain information from the students. Besides that, referential/ open questions were also used for stimulating students' opinion about something.

It was found that the teacher's questioning purposes were not only influenced by teacher assumption about asking questions but also the objective of the study. In the first session, the topic of the study was expressing preference so that the goal is that students are able to ask and give response about their preference. In the beginning, the teacher asked the meaning of certain words and sentences in order to check students understanding. After that, the teacher asked the students to practice.

In the second session, the topic of the study was about conjunction. The teacher was also merely asked the students to translate certain word and sentences. It was the teacher's way to check students' prior knowledge and understanding.

\section{Students' responses toward teacher's questions in terms of verbal language production in EFL classroom interaction}

Teacher was likely to push students to speak English. It could be seen in the research finding above that teachers' question could make it possible for students to practice their competence in target language. This finding confirmed Sadker's claim that proper ques- 
tioning type will result in the enforcement of students to perform their language competence as the respond to teachers' questions. In line with Sadker's claim, the teacher took the benefit of questioning into account. The teacher believed that the more intense she asked questions to students, the more active students spoke. Interaction among teacher and students would be built well. Moreover, students' language skills were also developed.

The research finding above shows that students' responses in form of words were still dominating. In the first session, it was found that $61 \%$ of students' responses were in form of words. The production of 10 words was the effect of employing display/closed question. In the other hand, students' responses in form of sentence were 3 sentences. It was the effect of employing referential/ open question.

In the second session, it was found that $76 \%$ of students' responses were in form of words. The production of 20 words was the effect of employing display/closed question. In the other hand, students' responses in form of sentence were 3 sentences. It was the effect of employing referential/ open question.

\section{Relationship among Types of Teacher's Questions, Pur- poses of Teacher's Questions and Students' Oral Responses}

The research finding above has provided further description about the relationship among types of teacher's questions, purposes of teacher's questions and students' oral responses. It has been discovered that teacher's questions which were categorized as displayclosed questions were generally used by the teacher to check students' understanding about the material that were being discussed. These types of questions can stimulate students' responses in form of word. Furthermore, types of questions which were categorized as referential-open questions were generally used by the teacher to look for certain information from students as well as students' opinion about something. In association with students' responses, these types of questions can stimulate longer students' responses that the previous one.

The present study respectively support the study conducted 
by Brock on the effect of teacher's questions on students' language production revealed that students' responses for teacher's referential questions were significantly longer and syntactically more complex. It was compared to students' responses for teacher's display questions which were short.

\section{CONCLUSIONS}

Based on the research finding and discussion, it could be drawn the conclusion of the present study which were designed to suit the objectives of the study. There are three objective of the present study; (1) to classify types of questions utilized by teacher in EFL classroom interaction.; (2) to examine purposes of questions applied by teacher in EFL classroom interaction.;(3) to identify students' responses toward teacher's questions in terms of verbal language production in EFL classroom interaction. The conclusion of the present study can be drawn as follows:

1. Dealing with the types of teacher's questions, it was discovered that the teacher utilized certain types of questions. Referentialopen questions that were used by the teacher were considerably fewer than the display-closed questions. Referential-open questions that can elicit longer responses had the percentage 31\%. On the other hand, display-closed questions had the percentage $69 \%$. These proportions of types of questions inhibit the students from performing their language competence extensively.

2. On the first session and the second session, the teacher asked students to translate some words or phrases by using some display/closed questions. It was done by the teacher in order to know whether students understand the material or not. Questions that are categorized as referential/open questions were widely used for looking for certain information from the students. Besides that, referential/open questions were also used for stimulating students' opinion about something.

3. Dealing with the students' responses toward teacher's questions, the teacher believes that the more intense she asks questions to students, the more active the students speak. Interaction among teacher and students would be built well. Moreover, students' 
language skills were also developed. The research finding above shows that students' responses in form of words were dominating. It was found that in all season $70 \%$ of students' responses were in form of words. The production of words were the effect of employing display/closed question. In the other hand, students' responses in form of sentence were 7 sentences. It was the effect of employing referential/ open question. 


\section{REFERENCES}

Aizikovits, Udi Eninav et.al., Good Question or Good Questioning: An Essential Issue for Effective Teaching, in $8^{\text {th }}$ CERME,Turkey, 6-10 February 2013.

Bloom, Benjamin S. et.al., (1956) Taxonomy of Educational Objective, handbook I: Cognitive Domain, London :Longman.

Brown ,H.Douglas S. (2001) Teaching by Principles,: An Interactive Approach to Language Pedagogy, $2^{\text {nd }}$ edition, New York: Longman.

Chaudron, Craig. (1988) Second Language Classrooms: Second Language Classrooms : Research on Teaching and Learning, New York: Cambridge University Press.

Chaudron,Craig, Classroom Research: Recent Methods and Findings, in Gabriele Kasper, Classroom Research-AILA Review, 1988.

Cohen, Louis, et.al., (2004) A guide to Teaching, $5^{\text {th }}$ Edition, London: Routledge.

Cohen, Louis, et.al., (2007) Research Method in Education, $6^{\text {th }}$ Edition, New York: Routledge.

Cotton ,Kathleen, “Classroom Questioning”. North West Regional Educational Laboratory (Online), available at: http://www. nrwel.org/scpd/sirs/3/cu5.html retrieved $16^{\text {th }}$ October 2012.

Creswell, John W.(2009) Research Design: Qualitative, quantitative, and mixed methods approaches, $3^{\text {rd }}$ edition, California: SAGE. 
Teacher's Questions in EFL Classroom Interaction ...

Dornyei, Zoltan. (2007) Research Method in Applied Linguistics: Qualitative, quantitative, and mixed methods approaches, , UK: Oxford University Press.

Eggins, Suzanne, Slade, Diane.(1997) Analyzing Casual Conversation,UK: Equinox Publishing Ltd.

Al-Farsi, Nawal Mohammed, Teachers' Questions in the Basic Education Classroom, in Classroom Research in English Language Teaching in Oman, Ministry Of Education sultanate Oman, available at: www.moe.gov.om/Portal/sitebuilder/sites/EPS/ English/.../Ch3.pdf, retrieved at: 20 December 2012, 06.40.

Griffee, Dale T. (2012) An Introduction to Second Language Research Method:Desigh and Data, US:TESL-EJ Publication.

Hitchcock ,Graham and Hughes, David. (1995) Research and the Teacher: a Qualitative Introduction to school-based research, New York: Routledge.

Hopkins, David. (2008) A Teacher's Guide to Classroom Research, $4^{\text {th }}$ Edition, London: Open university Press.

Kalatari ,Reza, (2009) “Techniques for Classroom Interaction", in International Journal of Language Studies (IJLS), Vol. 3(4).

Lynch, Tony, "Questioning Roles in the Classroom", in ELT Journal, vol. 45/3, 1991.

Ma , Xiaoyan, "The Skills of Teacher's Uestioning in English Classes", in International Education Studies, Vol. 1(4), 2008.

Millah, Dliyaul (Student Number: 3104206). Interaction Patterns and Speaking Categories in English Teaching in the Female Class of the Second Grade of MAN Surakarta PK (Specific Program). Thesis, Semarang: Bachelor Program of English Language Educa- 
tion of State Institute for Islamic Studies Walisongo (IAIN Walisongo), 2009.

Moleong, Lexy J.,Metodologi Penelitian Kualitatif, Bandung: Remaja Rosdakarya, 2009.

Al-Mu'aini, Hussein Ahmed, The Effect of Referential Questions on Learners' oral Contributions, in Classroom Research in English Language Teaching in Oman, Ministry Of Education sultanate Oman, available at:www.moe.gov.om/Portal/sitebuilder/ sites/EPS/English/.../Ch3.pdf, retrieved : 20 December 2012, 06.37 .

Nishimura, Toshihiro.Teacher's Questioning Techniques Employed in Japanese Senior High School's English Class and the perceptions of three Japanese English Teachers. Thesis, UK: MSc TESOL (Edinburg University), 2012.

Nunan, David. (1992) Research Method in Language Learning, New York: Cambridge University Press.

Özcan, Seda, The Effects of Asking Referential Questions on the Participation and Oral Production of Lower Level Language Learners in Reading Classes ,Turkey: Middle East Technical University, 2010, Unpublished Thesis.

Richards ,Jack C et.al, Longman Dictionary of Applied Linguistics, UK: Longman Group, 1985.

Richards , Jack C. and Lockhart, Charles, Reflective Teaching in Second Language Classrooms, New York: Cambridge University Press, 1996.

Sadker ,David, et.al.. , (2011) “Questioning Skill”, in James M. Cooper, et.al., Classroom Teaching Skill, CA: Wadsworth. 
Teacher's Questions in EFL Classroom Interaction ...

Shen, Ping, Yodkhumlue, Butsakorn, Teacher's Questioning and Students' Critical Thinking in College EFL Reading Classroom. The 8th International Postgraduate Research Colloquium: Interdisciplinary Approach for Enhancing Quality of Life IPRC Proceedings (online) available at: bsris.swu.ac.th/iprc/8th/044 539 Pingshen.pdf , retrieved: 17 December 2012, 11.11.

Sari, Yuli Puspita, An Analysis of Teacher's Questioning Strategies in a Public Senior High School in Bandung Bandung: Universitas Pendidikan Indonesia, 2011, Unpublished Thesis.

Sulistiyowati ,Eny, Levels of Questioning Used by a Teacher in a Classroom at Senior High School. The Case Study of a Teacher and Students of Class XII of SMAN 1 Jakenan, Kabupaten Pati in the Academic Year 2011/2012, Semarang: Universitas Negeri Semarang, 2012, Unpublished Thesis.

Yuliyanti, Teacher's Questioning Behavior in an EFL Classroom Bandung: Universitas Pendidikan Indonesia, 2008, Unpublished Thesis.

Yanfen, Liu and Yuqin, Zhao, A Study of Teacher Talk in Interactions in English Classes, in Chinese Journal of Applied Linguistics, Vol. 33(2), 2010.

Yang, C. C. R, Teacher questions in second language classrooms: An investigation of three case studies. Asian EFL Journal, 12(1), 2010.

Website:

Nordquist, Richard, Question, available at: www.grammar.about. com $/ \mathrm{od} / \mathrm{pq} / \mathrm{g} /$ questionterm.htm, retrieved 07 February 2013, 13.46 